the relatively young martian meteorite EETA 79001 seven years ago were of martian rather than terrestrial origin. One journalist was given an exclusive interview with Pillinger and the following day's headline read: 'Life on Mars was found by Britons'.

Pillinger also decided to publicize separate results, obtained just one week before the meeting, of an isotope analysis of small amounts of carbonate taken from the much older meteorite ALH 84001. These results appeared to corroborate the findings of the NASA researchers by suggesting that the carbonates were formed from microbiallyproduced methane.

Pillinger says the researchers do not regret discussing unpublished research directly with the media, even though he was aware that this might reduce its chances of being published by some journals. He says such an action was necessary for the meeting to achieve one of its main objectives - to generate publicity for British science.

Taylor says he disagrees with suggestions that the meeting amounted to 'science by press conference', preferring to describe Pillinger's actions as "instant peer review". The minister also rejects suggestions that such procedures encourage a 'publicize first, publish second' mentality. "I don't think scientists will depart from the desire to publish or get citations. Colin Pillinger is already well established. He quite naturally felt he could take a risk. I give him credit for that."

team, EETA 79001.

Furthermore the pattern of PAH types and distributions is an "almost exact overlay" of what McKay's group reported for their meteorite, Allan Hills 84001, says Bada. But he adds that the amino acids and hydrocarbons are almost certainly from Antarctica, not Mars. Bada's detailed analysis of ice from the Allan Hills region shows that it's "loaded with [PAHs], and it looks just like what's in the meteorite".

These and other nagging doubts have led even NASA researchers - including those working on plans to revamp the agency's strategy for exploring Mars to be extremely cautious in supporting the McKay team's conclusions. According to John Logsdon, however, of the Space Policy Institute at George Washington University, the 'discovery' has already had a significant effect at NASA.

Logsdon points out that the justification for robotic exploration of the planet (the US Mars Global Surveyor spacecraft, the first of three missions headed for Mars this year, was scheduled to launch this week) has shifted more explicitly to include a search for life. And he says that extreme cuts to NASA's budget floated in some budget projections earlier this year now seem unlikely.

Meteorite researchers also will

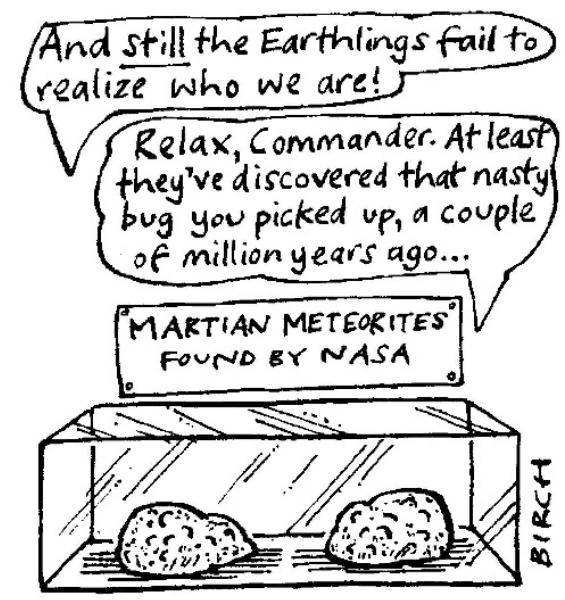

Monica Grady of the Natural History Museum in London agrees that scientists have a duty to communicate to the public, although she adds that she is personally not in favour of portraying science "as a competition or as a conflict".

Grady, who is the third author on the 1989 Nature paper, says she is less sceptical of the NASA announcement of life on Mars than she was in August, and acknowledges that she is "a great believer that we will find life in a planetary system". But she emphasizes that definitive answers to this question will be found only by further research and from future Mars missions.

Ehsan Masood

benefit from the finding. NASA and the National Science Foundation (NSF) are each spending about $\$ 1$ million to fund work that might settle whether the Mars rocks contain signs of life, and will ask for proposals from the scientific community later this month.

Forty-seven research teams already have samples of the twelve known martian meteorites, and 16 more have requested samples. Allocation of samples has been suspended until after the NASA/NSF solicitation, however, partly so that the committee in charge of deciding who receives samples can strengthen its expertise in certain scientific areas, including palaeobiology and organic geochemistry, according to Marilyn Lindstrom, a meteorite curator at the Johnson Space Center. Lindstrom says that samples will be allocated independently of funding decisions, and that the NSF and NASA will coordinate their research funding so as not to overlap.

Many space scientists hope the additional money and attention will draw new blood to the field and lead to interdisciplinary collaborations. McKay's team plans to continue looking for cellular structure in its microfossils and pursuing other investigationa, but is keeping quiet about how and when it might release further results. Tony Reichhardt

\section{Settlement deprives peer review of its day in court}

Washington. A Seattle-based biotechnology company has agreed to pay $\$ 21$ million to a rival which claimed that it stole information subsequently used for a patent application from a paper under confidential review for publication in Nature.

The out-of-court settlement, which was reached on 31 October - only days before the case was due to be heard in a Seattle courtroom - deprives the science community of a legal judgement on the confidentiality of the peer review process.

Cistron, a small, New Jersey-based company, had taken Immunex of Seattle to court on the basis that an Immunex scientist had taken data on a protein, interleukin-1 (IL-1), from a paper submitted to Nature in 1984 by a Cistron team, and that Immunex had then used it for its own research and patent applications. The paper was rejected for publication, and IL-1 turned out to have little commercial significance.

Evidence for the theft included a set of errors in a DNA sequence in the original paper, which was later repeated in Immunex's patent applications. Immunex denied stealing the data. But according to documents filed to the court, the company was preparing a defence which argued that the peer review process is not legally confidential, and that material cannot be regarded as confidential once submitted for publication in a peer-reviewed journal.

Immunex has now agreed to pay \$21 million to Cistron over a three-year period and assign some of its patents on IL-1 to the New Jersey company. When prospects for IL-1 were brighter, Immunex received more than $\$ 100$ million from a major pharmaceutical company for a share of its work on the protein.

Cistron initially sued for $\$ \mathbf{1 5 0}$ million, which it later reduced to $\$ 70$ million. A joint statement from the two companies said that the settlement "was made without any concession or admission of liability".

Henry Grausz, chairman of Cistron which has seven employees and had sales last year of just $\$ 700,000$ - said it "believes it holds a strong position in the IL-1 area". Immunex has 800 employees and annual sales of $\$ 160$ million. It is now fighting to regain some of the settlement costs from its liability insurers.

Had the case gone to court, the outcome could have hinged on whether material submitted to a peer-reviewed journal is legally confidential. "If it had come to court, the point would have been decided," says Sir John Maddox, former editor of Nature, who was due to appear as an expert witness for Cistron.

Colin Macilwain 